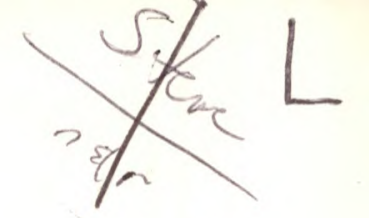

\section{AN OBJECTIVE WAVEFORM COMPARISON TECHNIQUE}

by

George Y. Baladi and Donald E. Barnes Structures Laboratory

U. S. Army Engineer Waterways Experiment Station P. O. Box 631, Vicksburg, Miss. 39180

\section{UNIVERSITY OF ILLINOIS
LIBRARY AT URBANA-CHAMPAIGN ENGINEERING}

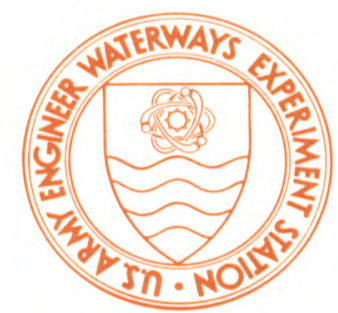

October 1983

Final Report

\section{RECEIVED}

JUN 241985

METZ REFEREMCE ROOM

\section{University of Illinois Metz Reference Room BI06 NCEL \\ 208 N. Romine Street} Urbana, Illinois 61801

Approved For Public Release; Distribution Unlimited

\author{
Prepared for Defense Nuclear Agency \\ Washington, D. C. 20305
}

Under DNA Task Y99QAXSB, "Ground Shock Predictions"

Work Unit 00020, "Waveform Comparison Tonhninunc"

UNIVERSITY OF MICHIGAN 